\title{
Research on the Levirate Marriage for the Han Chinese during Yuan Dynasty
}

\author{
Zongyan Jiang $^{1}$ \\ ${ }^{1}$ Law School of Beijing Normal University, Beijing, China \\ Correspondence: Zongyan Jiang, Law School of Beijing Normal University, No. 19, XinJieKouWai St. HaiDian \\ District, Beijing 100875, P. R. China. Tel: 86-186-9317-3608. E-mail: jiangzongyan1903@163.com
}

Received: June 11, $2019 \quad$ Accepted: July 11, $2019 \quad$ Online Published: July 29, 2019

doi:10.5539/ass.v15n8p104 URL: https://doi.org/10.5539/ass.v15n8p104

\begin{abstract}
The levirate marriage has been continued for thousands of years in the ancient time of China until after the People's Republic when it died out. In Yuan Dynasty, the levirate marriage was gradually ascended to state law from national habits; its position was so important that it was considered as the customs of the country, later it gradually moved towards collapse. The variation of laws as well as regulations for the levirate marriage reflect the process of which the two cultures of the Mongolian people and Han people blended continuously. Starting from the research on the policy of the levirate marriage for the Han Chinese, this article explores for the jurisdiction and control of rulers in Yuan Dynasty for the Han Chinese to disclose the ideological features of laws in Yuan Dynasty, which explore for the conflict and coordination of law culture in grassland of the law culture in central plains.
\end{abstract}

Keywords: the levirate marriage, customary law, state law, institutional transformation

The institution of marriage is the institutional guarantee for human beings to live and multiply. In the process of historical development, the pattern for the establishment of marriage can be in varied forms, which it is by no means an isolated case. The levirate marriage is one of the most ancient wedding customs of the ancient people in primitive society. The word for the levirate marriage emerged in the ancient codes and records of Yuan Dynasty at the earliest time. It is the method for the establishment of marriage through which other male relatives in the family of the husband except for the biological son accept the widow as his wife after the death of her husband. There is a great difference between this policy of marriage and the so-called licentiousness and promiscuity. It is implemented with strict limitations. Only the younger generations or those of younger age may accept the widow of the elder generations or those of older age. It cannot be done in a reverse way. Due to the limitations of natural the environment, the influence of lifestyle and the guidance of cultural idea, the minority regimes in the north of China commonly practiced policy for the levirate marriage. Its history is so long that it has not been stopped for thousands of years, "the levirate marriage between sons and wives of their fathers among nobilities and ordinary Mongols before and during the Yuan period, and proves that the levirate marriage between men and women of different generations in Mongol-Yuan royal family, was base on the old marriage tradition of Inner Asian nomads." (Liu, 2019, p. 141) Under the influence of it, before the establishment of the Yuan regime, there has already been a phenomenon for the levirate marriage among the Han Chinese in the north. After the entry and host of the Mongolians in the central plains, with the continuous deepening for the degree of cultural combination, there is also some change of the Han Chinese for the recognition on marriage order.

\section{The Changes of the Policy for the Levirate Marriage Among the Han Chinese in Yuan Dynasty}

\subsection{The Legalization for the Levirate Marriage Among the Han Chinese at the Early Stage of Yuan Dynasty}

"To follow the respective customs" is the core philosophy for the civil legislation in Yuan Dynasty, so it is in the field of marriage. In 1271, Kublai changed the reign title as Yuan for which Yuan Dynasty was established. As a kind of marriage policy, the levirate marriage was recognized by the central regime in history for the first time, in December of the eighth year of Zhi Yuan period under the sovereignty of Yuan Huizong (1271A.D.) the official of the central government issued an imperial edict: "The elder brother may accept the widower of the younger brother as his wife, the younger brother may accept the widower of the elder brother as his wife." (Chen, Zhang, Liu, \& Dang, 2011, p. 653) Since then there is a legal accordance for the Han Chinese to 
implement the levirate marriage. There is adjudication rule in accordance with precedents and the integration of specific cases to make legal, logical and reasonable judgment for the proceedings of case in Yuan Dynasty. By October in the ninth year of Zhiyuan period (1272A.D.), the feudal official accepted a case for the adultery of the husband's younger brother and his wife. Zhen Nunu passed away in the fifth year of Zhiyuan (1268A.D.), his wife Wang Yinyin lived in widowhood at the family of her husband. Zhen Wowo, the brother of Zhen Nunu had not been married; the two had adultery and escaped with Wang Yinyin being pregnant. The judge released Zhen Wowo who was in custody in accordance with the above stated imperial edict and ordered Zhen Wowo to accept Wang Yinyin as his wife. (Chen, Zhang, Liu, \& Dang, 2011, p. 653) This imperial edict is the main reason for the popularity of the levirate marriage among the Han Chinese in the beginning of Yuan Dynasty; it is also the important legal accordance of the feudal official to judge for the case with the request of the levirate marriage. The attitude of the ruler is quite tolerant for the male who requests to practice the right for the levirate marriage. It does not interfere in an active way; on the contrary, it offers a certain encouragement.

In the tenth year of Zhiyuan period (1273), Fu Er passed away due to illness, his younger brother, Fu Wang Bo, would like to accept his widower Niu Wang Er as his wife. He raped her after she had refused his proposal for which Niu Wang Er was forced to go back to her home for the widowhood. After the investigation by the official feudal, it was found that Fu Wangbo already had a wife, and neither his father Fu Yi, nor his mother A Qiu Yi Xu agree for $\mathrm{Fu}$ Wang Bo to accept Niu Wang er, they agreed for their daughter in law to go home. According to the regulations in Tong Zhi Tiao Ge (通制条格): “Those who have already married marry, even if the emperor releases a pardon, he will be forced to divorce, Mongolians are exceptions." (Fang, 2001, p. 163) Nevertheless, when it is against the current law and the related parties are against the levirate marriage, the feudal official still judged for the permission of Fu Wangbo to accept Niu Wang Er as his wife for which it can be seen that the official held a positive attitude towards the enhancement for the levirate marriage among the Han Chinese.

Women whose fiancé died after the engagement were also included in the scope of objects for the levirate marriage. On March $22^{\text {nd }}$ in the tenth year of Zhiyuan period, Zhao Lianer and Yi Yue'er from Huazhou were engaged, it was not until the date of marriage that Zhao Lianer passed away, the family of the male would like to succeed Yi Yue'er for marriage with the second son, the family of the female did not agree. The family of the male reported filed a lawsuit to the feudal official, and the official held the opinion that although the two were not married, they had been engaged for which they were legal husband and wife, according to the imperial edict issued in the eighth year of Zhiyuan period, it was judged that the younger brother of the husband may accept his elder sister in law to be the member of his family as his wife. (Chen, Zhang, Liu, \& Dang, 2011, p. 654)

In the real case, the younger brother of the husband who has not reached the legal age for marriage may also get married with the elder sister in law who is an adult or even has even remarried. In May of the tenth year of Zhiyuan period, Guo Qilv, the son of Guo Aqin was engaged with Li E'er, the daughter of Li Dade, the betrothal presents had not been handed over. At this moment, Guo Qilv passed away. The family of Guo would like to succeed Li E'er for marriage with their second son, Guo Dong'er. At the moment their second son was only twelve which was far from the legal age for marriage. Li Dade did not agree with the marriage and determined that her daughter E'er be married with Chen Lv'er and had accepted the betrothal presents from the family of Chen. The official at the feudal government held the opinion that since Guo Dong'er was the real younger brother of GuoQilv, he should have the right for the levirate marriage, although Li E'er was just engaged for which she was to be the member in the family of Guo, she was still the daughter in law for the family of Guo. It was judged for GuoAqin to seek for the marriage of LiE'er in accordance with the six manners and ordered Li Dade to return the betrothal presents to the family of Chen. (Chen, Zhang, Liu, \& Dang, 2011, p. 654)

For the younger brother of the husband who had been engaged, the judge even violated the basic marriage structure of the Han Chinese for the one husband one wife policy without the consideration for the imperial edict of divorce for those who marry with wife and ordered the interested party to accept two wives. In the tenth year of Zhiyuan period, Liu Er committed suicide, his younger brother Liu San accepted his sister in law, A Guo, the Ministry of Revenue in Feudal China at the central government judged that Liu San may accept A Guo and his original wife Hu Chage as his wives together. (Chen, Zhang, Liu, \& Dang, 2011, p. 654)

The situation of encouragement for the levirate marriage had been extending until the end of Kublai's rule; ruler after him no longer held the positive attitude towards the implementation for the levirate marriage among the Han Chinese. In the tenth year of Zhiyuan, Liu Gui requested for the levirate marriage with his sister in law Liu Ama at the feudal official. Liu Ama was over 50, and she had been living in her widowhood without marriage since the death of her husband, Liu Guoyu due to illness. She had a son aged 36 whose name was Liu Abing. (Chen, Zhang, Liu, \& Dang, 2011, p. 655) For this situation, the Ministry of Revenue in Feudal China made the judgment of prohibition for the levirate marriage. First of all, the succeeded one had been in the widowhood for 
many years. Secondly, since Liu Ama was supported by her adult son, she had been living in a separate house. In addition, the age of Liu Ama is large for which she had lost the value for the levirate marriage. Therefore, the official made the exceptional judgment for the prohibition of the levirate marriage. In this case, the judges no longer ordered the succeeded one to be succeeded by force in accordance with the laws and regulations; instead, they began to consider the actual situation of the case for which they made more humanized judgement without violating the feudal ethics. This is also the specific reflection of influence generated by the guiding ideas for the case treatment of justice, state law and human emotion on practice in the process of continuous combination for the culture of the Han Chinese and the Mongolians. At the time, the official prohibited the behavior for the elder brother to accept the wife of his younger brother as his wife; it is defined in The History of Yuan Dynasty :the Record of the Criminal Code (元史·刑法志): “For elder brothers who accept the wife of his younger brother, as his wife shall be beaten by the rod for one hundred and seventy times, it is ninety-seven times for women, and they shall be separated." (Song, 1999, p. 1755) Even Mongolians who implement this kind of the levirate marriage are considered as the behavior against the ethics and morality. By the development of time, more and more cases with the judgment for the prohibition of the levirate marriage emerged in The Collection of the Laws of Yuan Dynasty (元典章). However, the number of Han Chinese who reported to the feudal official for the conflicts generated by the implementation of the levirate marriage increased with no reduction.

\subsection{The Limit and Prohibition for the Levirate Marriage Among the Han Chinese at the Middle and Late Yuan Dynasty}

After the middle and late Yuan Dynasty, with the further deepening for the combination of Mongolian and Yuan culture, the ruler was more determined for their attitude against the levirate marriage, the levirate marriage without following the respective customs was prohibited and many limitations were set for the levirate marriage following the respective customs.

\subsubsection{The Gradual Control for the Levirate Marriage Among the Han Chinese During the Period of Chengzong}

During the period of Chengzong in Yuan Dynasty (1295A.D. - 1307A.D.), the official enhanced the limitation for the levirate marriage among the Han Chinese. In March of the second year of Yuanzheng period (1296A.D.), the elder son of Li Azhou, Li Jixian passed away, Li Fuzheng, the second son who was monk at the moment resumed secular life for the accumulation of hair in hope of succeed her sister in law, Zhang Baonu who had been in widowhood, Zhang Baonu refused his proposal and remarried to another man. In the opinion of the censorate, Li Fuzheng was a monk, the permission for his right of the levirate marriage is against the convention, and therefore, the official acknowledged the original marriage and banned the right of her husband's younger brother for the levirate marriage. (Fang, 2001, p. 149)

In October of the fourth year of Chengzong Dade period (1300A.D.), a slave named Li Baijia in Henan filed suit against his master, Liu Huanzhu determined for the marriage of his younger sister, Liu Guaiguai with Li Sishi for which he had given dowry for marriage, at the moment, Li Sishi passed away before the marriage. Li Wu'er, who was the younger brother of Li Sishi, would like to succeed the marriage with Liu Guaiguai, yet he had already married with a wife. The ministry of rites in feudal China banned Li Wu'er for the levirate marriage with Liu Guaiguai for the fact of which Liu Guaiguai had not entered the family of Li and could not be considered as the daughter in law for the family of Li. (Fang, 2001, p. 149) The daughter in law who had not entered the family was no longer listed in the scope for the levirate marriage. This is the determined judicial principal in the later rule of Kublai. With the addition to the ban for those who have wife to marry, naturally this succession would not be supported by the judge.

Zhao Yingxi, who lived at Yan'an Road in Shaanxi with no sons to support her, would like to accept Wang Anrang as her son in law for the support of her life. In November of the fifth year of Dade period (1301A.D.), Wang Anrang passed away without fulfilling the time limit, his brother Wang Anjie would like to succeed his elder sister in law for marriage. (Fang, 2001, p. 151) Under the condition of the death of her son in law for the support of her life due to illness, the Ministry of Rites in Feudal China considered that the elder was old with no support; it ordered the widow to accept another son in law and banned the levirate marriage. This case is the classical precedent of which the younger brother of the son in law for the support of the elders who passed away is banned as the succeeded.

In September of the sixth year of Dade period (1302A.D.), Guo Wen at Pingyang Road accepted the nephew of Li Ju, Ben Niu as the son in law who leaves his own family, Ben Niu passed away in the year of marriage. Guo Wen asked the marriage broker to determine whether there is anyone who can practice the levirate marriage in the family of Li and married his daughter to Bao Wang, after that Li Ju suggested his son, An Sen, succeed Xiuge. (Fang, 2001, p. 151) According to the laws and regulations, the widow can only be succeeded after the death of 
her husband, and she can only marry to others under the condition that there is no one for the succession or the one for the succession does not practice the levirate marriage. In this case, four years after the death of Ben Niu, the family of Guo married their daughter to another family after obtaining the approval from the family of Li. The Judge confirmed the existence of the marriage relationship available and banned the younger brother of the husband for the practice of the levirate marriage; this case also became the precedent for the denial of the younger brother of the husband for the practice of the levirate marriage after the re-marriage of the widow.

\subsubsection{The Strict Limitation for the Levirate Marriage Among the Han Chinese During the Period of Renzong}

During the period of Renzong period (1312A.D.-1320A.D.), the concept of value in the culture of Han won more support among the people, the ruler started to implement the stricter limitation on the levirate marriage between Han Chinese. In the second year of Yanyou period, when Renzong was the ruler in Yuan Dynasty (1315), the famine was serious in the region of Jiangsu and Zhejiang; the phenomenon of the pawn for wives among people at the bottom level was quite common. In the cases of this time, after the wife was sold by her husband, she had another child, and her ex-husband passed away, the younger brother of her ex-husband would like to succeed her sister in law in accordance with the common rule. In the opinion of the Ministry of rites in Feudal China at central government, the pawn of a wife is induced by the poverty of the family, and it is not done willingly. Since the ex-husband passed away and the wife had children with the current husband, the younger brother of her ex-husband should not succeed the sister in law in accordance with the common rule. (Chen, Zhang, Liu, \& Dang, 2011, p. 662) When it came to the middle age of Yuan Dynasty, the succession between peers still existed among the people, this case is quite similar to the previous case of which "the sister in law at the family who had been in the widowhood married to another family", in the special case with the pawn of a wife, the younger brother of her ex-husband lost the right for the levirate marriage. It can be seen from the reply in this case that the official held the attitude of denial to the levirate marriage among Han Chinese.

In February of the fifth year of Yanyou period (1318A.D.), after the death of Tian Qianyang, the husband of A Duan, A Duan independently raised four children. During the observation of mourning at her parents' family, her mother in law, A Ma brought her son, Tian Wuer to request Duan Zong, the father of A Duan to succeed A Duan to her son, Tian Changyi. In the opinion of Duan Zong, her daughter was in the observation of mourning and she had four children to be raised, it was not possible for her to be succeeded. A Ma, her mother in law forced A Duan to stay at her family with an excuse. Tian Changyi, the younger brother of her husband raped A Duan by this opportunity with the help of another younger brother, Tian Wu'er. In the opinion of the ministry of punishment in feudal China after the acceptance for the case, the behaviors of the two younger brothers are against the morality and the human relations. It was judged that Tian Chanyi should be punished in accordance with the precedent of "raping a woman with no husband" his younger brother Tian Wu'er was judged in accordance with the criminal he had done. (Chen, Zhang, Liu, \& Dang, 2011, p. 656) In the middle and late Yuan Dynasty, the application for the levirate marriage must be based on the willingness of both parties, the behavior for the levirate marriage by force had been strictly prohibited by the official, according the criminal law, it would be determined as the crime of "raping a woman with no husband".

\subsubsection{The Prohibition for the Levirate Marriage Among Han Chinese During the Period of Wenzong}

During the period of Wenzong, the implementation for the levirate marriage among Han Chinese for the younger brother to succeed the wife of the elder brother was raised from limitation to prohibition. The official issued the policies such as "all the Han Chinese, people in the south are prohibited for younger brothers to succeed the wife of the elder brothers." "except for their customs, if a younger brother accepts the wife of his elder brother, and a son accepts the concubine of his father will be punished". (Song, 1999, p. 1755) The pattern for the levirate marriage with the younger brother succeeding the wife of his elder brother was only limited to the minorities who have the customs for the levirate marriage to implement, Han Chinese were not allowed to implement the levirate marriage in any pattern. It is recorded in The History of Yuan Dynasty: the Record of the Criminal Code (元史·刑法志): “Younger cousin should not marry the widow of his elder cousin, otherwise it shall be considered as adultery" (Song, 1999, p. 1755). In the beginning when the Mongolians entered and hosted the central plains, the ruler expected to rule the country with their original social customs and habits and laws. However, with the large amount of application for the culture of Han Chinese and the daily combination of the Mongolian and Han culture, the legal and cultural value and the Confucians' etiquette of the Han Chinese was gradually penetrated into the legal ideology of the Mongolians during Yuan Dynasty. The policy for the levirate marriage gradually walked to its decadence. The experience of encouragement in the beginning, the limitation in the middle age and the strict prohibition in the later stage sufficiently reflects the change of the ruler for the control of the country. 


\section{The Situation of Resistance Against the Levirate Marriage Among Han Women}

According to the statistics of the data available now, there are 359 virtuous women in Yuan Dynasty, there is emergence of virtuous women in all the nations, among the women for the resistance against the levirate marriage, Han women are in the front of which their cases are all over the Collection of Laws in Yuan Dynasty (元典章).

"Women are powerful actors in customary marriage, which allows them to overcome a range of structures of power.” (Moore, 2015, p. 836) Da Yuan Tong Zhi Tiao Ge (大元通制条格) and The History of Yuan Dynasty: Biographies of Exemplary Women (元史·列女传) recorded that between the periods of Zhizhi when Yingzong was the emperor of Yuan Dynasty, two Han women were not willing to be succeeded for the preservation of chastity after the death of their husbands for which they were awarded by the imperial court: after her husband was drowned, Wang, the wife of Zhao Mei swore that she would preserve the chastity and would not seek for marriage with other men. Her father and mother in law would like to succeed Wang for their nephew, Wang refused to be succeeded with the reason of "no marriage for the chastity of women" (Song, 1999, p. 3005). Under the great pressure of her father and mother in law, Wang knew that she was not able to resist any longer, she hanged herself to keep her chastity. After the death of Li Shi'an in Chengdu, his younger brother Li Shixian would like to succeed his sister in law, Wang for which Wang stubbornly refused. She cut her hair with a knife and her ears for which the injury was serious. Relatives were astonished for her behavior and cured her for hundreds of days before the recovery. (Song, 1999, p. 3005)

In the short ten years under the rule of the Mongolians in the land of central plains, although the cultures and customs and the concept of values of minorities had a huge impact and shaking for the Han Chinese, the culture foundation in the land of Han for thousands of years would not be fundamentally changed by the temporary guidance of the ruler's policy. During the beginning of Yuan Dynasty, when the policy of encouragement and support for the levirate marriage was implemented, many Han women were not willing to be succeeded and checked evidence of both parties at court with the family of their husbands. After the start of limitation for the behavior of the levirate marriage among the Han Chinese in the middle and later stage of Yuan Dynasty, women who observed the mourning for their husband who had passed away to preserve the chastity were everywhere. In order to right the despotic power of their father and mother in law, they even had self-injury and death to show their chastity. Regardless of the lagged doctrine of which they may maintain, their behavior of fighting for their own value with their weak body is worthwhile for the ruler to award.

\section{The Legal Analysis on the Transformation of the Policy for the Levirate Marriage Among Han Chinese in Yuan Dynasty}

\subsection{The Reason for the Han Chinese to Gradually Accept the Levirate Marriage in the Beginning of Yuan Dynasty}

Yuan is the first huge and unified feudal empire established by the nomadic people in the north in the history of China, the collision, conflict and combination of the customs and culture between the Mongolians and Han were inevitable. "In Mongolia, levirate marriage was rooted in the soil of the long-established grassland culture, which existed as far back as the huns." (Liu, 2019, p. 94) There was also serious difference for the attitudes of the Mongolians and Han towards the levirate marriage. Since the release of the imperial edict from Yuan Shun Emperor for the levirate marriage among Han Chinese, the levirate marriage with the concubine of father, the widow sister in law, the uncle's wife in the family of both his father and mother among Han Chinese became legal and reasonable, cases of succession by force against the willingness of the widow for the preservation of chastity frequently occurred. This pattern of marriage ran in opposite direction from the traditional morality of Han Chinese, why is that the levirate marriage was still popular among the Han Chinese during the reign of the Mongolians in Yuan Dynasty and formed the situation of which each nation has something of their own customs?

\subsubsection{The Demand for the Increase of Population}

After the rise of the Mongolians, the nation continuously launched wars for expansion, and the people were slaughtered, the farmlands were damaged, the assets were robbed during the south march of the army. During the time of Genghis Khan, most of the Han Chinese in the south were forced to migrate to the north for which large number of farmlands were deserted for which it appeared with the situation of a rundown and depression. When Ogodei conquered Jin, many Han Chinese were slaughtered. During the south march of Mungo, the population in the basin of Sichuan, the Yungui Plateau and Lianghuai River Basin was dramatically reduced. It was almost extinction after the march of the army and became a man free zone. The war lasted so long, people were scattered and away from their home, disease was indulged in wanton massacre for which the population was 
reduced sharply. "There were 7.68 million households with more than 45.81 million people in the seventh year of Jin Tai He, after Ogodei conquered Jin, only 870 thousand households with about 4.75 million people were left, including Mongolia, in accordance with the statistics in 1235. In the five years from the sixteenth year of Jiading in the rule of the emperor Song Ning Zong of South Song Dynasty to the period of Jingding in the rule of the emperor of Song Li Zong, the population dropped from 12.67 million households with 28.32 million people to about 5.69 million households with 13.02 million people." (Liu, 2004, p. 130)

People are the base for the maintenance of governance, with the economy in depression at the beginning of Yuan Dynasty, and the rulers from Mongolia were aware that to consolidate the political power, they must change the savaged ruling strategy of nomadic people. Under the suggestion of the remained ministers from Jin with higher degree of Chinese localization, Kublai announced to increase households as soon as possible. The guarantee for the remarriage of women in appropriate age who have lost their husbands is one of the preconditions for the increase of population and the encouragement of fertility. Many women who have lost their husbands were at the age of fertility or had not experienced fertility. Some women had not even walked out of their house, if it can be guaranteed that these women can be remarried successfully, the population issue may be solved in a better way. The procedures for the levirate marriage are simple with less cost of money, and it meets the policy of the government for the increase of population. The purpose for the release of the imperial edict from the emperor Yuan Shun was not only for the promotion of the Mongolian culture among the Han Chinese and the enhancement for the effective governance, it was also for the encouragement of fertility in hope of achieving the effect of population increase in the wide Han Chinese.

\subsubsection{The Influence of Economic Factors}

It is not hard to see from the cases recorded in the historical materials, the group with the frequent the levirate marriage among the Han Chinese in Yuan Dynasty was concentrated in the middle and lower level of the society; it was most popular in the rural and remote area. Since Zhou in China, the marriage procedures in the feudal society of China are conducted in accordance with the six manners in "Li Ji, Hun Yi" of which "wedding gifts" and "wedding ceremony" has been what matter most. The law of Yuan changed the "wedding gifts" as "wedding coins" for which it expressed the internal meaning of this etiquette in a clearer way. In the beginning after the establishment of Yuan, many things waited to be done in all the fields, most of the male youth of the right age in ordinary families cannot have wife for the successful extension of their family with offspring. Under the condition when the family of the male had already lost a youth for labor, if the younger son married another girl, not only must he provide the wedding gifts in accordance with the habits in the six manners, and the new wife naturally would not be able to adapt to the family life so well as the women who had rich experience for the delivery and life. With the wars for many years, the requirement of the idealist philosophy in Song Dynasty for ethical virtue no longer mattered in the heart of ordinary people, for most of the people at the bottom level, it was not easy to survive the continuous wars, morality would be minute compared with the offspring and the inheritance of family. There is no complicated procedures for the levirate marriage with low cost, for people at the bottom of the society who met the condition for the levirate marriage; it was no doubt a pattern of establishment for marriage with multiple advantages.

\subsubsection{The Result of Cultural Combination}

The traditional Confucian ideas consider the chastity and virginity as the guidance of priority for the women to observe, women who have lost their husbands should be faithful to their husband who has passed away and shall not remarry. The neo-Confucianism objects the remarriage of women. It requires the people to have higher moral standard, and women must be faithful to their husband. Remarriage is not allowed, let alone the possibility for the implementation of the levirate marriage. The ruler awarded the example of chastity from the imperial curt for which the act of women for the preservation of chastity was considered as the emblem for the spirit of chastity and righteousness. "In this sense marriage goes beyond mere mating, which should only strengthen the influence of cultural history." (Minochera, Dudac, \& Jaeggia, 2018, p. 185)

With the disintegration of the regime for North Song Dynasty, the neo Confucians also experienced a huge impact. In Song Dynasty, the north regions were under the governance of West Xia and Jin for a long term, these two nations have the customs for the levirate marriage, and therefore, the Han Chinese under the governance of these two nations had recognized and accepted the policy for the levirate marriage. And with the continuous wars for years, the opportunity of people for the receipt of culture and education became fewer and fewer, feudal ethics was not in the supreme ideological position in the hearts of people at the bottom level. Not only did the levirate marriage neglect the chastity of women, it was against the feudal ethics, it was the act of incest in the eyes of Han scholars. However, this sound of objection was only originated from the landlord class in the region 
under the governance of South Song, looking from the region where the cases for the levirate marriage occurred; they were basically concentrated in the regions north of the Yangtze River. In the collective life for a long time, mutual influence was inevitable to be generated between the culture of minorities and the culture of Han Chinese. The promotion for the levirate marriage among the Han Chinese in the beginning of Yuan Dynasty is also the important expression of the Mongolian ruler for the promotion of their lifestyle and value concept to consolidate the base for their governance.

\subsection{The Decadence of the Policy for the Levirate Marriage in the Middle and Later Stage of Yuan Dynasty}

\subsubsection{The Demand for the Development of Economy}

With the development of the society, the legislation of Yuan Dynasty began to be converged with the traditional legal value of Han Chinese which can be reflected from the variation of the attitudes of the ruler in Yuan Dynasty towards the legislation for the levirate marriage among Chinese people. They have also experienced the process from the default to encouragement, and then limitation and to the probation at last for their attitudes towards the levirate marriage among the Han Chinese in the judicial practice for which there must be an internal reason in the deeper level.

After the Mongolians conquered Jin, they applied Yelv Chucai, the aristocrats and bureaucrats who had been localized by the Chinese during the war between Liao and Song. During the war between the Mongolians and Jin, Temujin proposed to kill all the Han Chinese and transformed the farmland into pasture to extend the original habits and customs of the Mongolians and guarantee the supply of food for the army during the war. This idea was stopped by Yelv Chucai. In his opinion, the ruler should keep the farmlands to increase the financial revenue. In the beginning since the establishment of Yuan, Kublai set the ministry of agriculture as the government organization which was dedicated to the administration of agriculture. With the extension of time for governance, the aristocrats who had settled in the land of Han were gradually adapted to the lifestyle of farmland area and cultivated large number of farmlands with the hiring of people for rental plant. In order to enhance the development of agriculture, they even built water conservancy projects, organized the rivers and governed the Yellow River. The attention on the agriculture without the suppression of merchants is a basic national policy of Yuan Dynasty, the central government directly controls the foreign trade. Port reeves were set at the five port cities which are Quanzhou, Shanghai, Wenzhou, Hangzhou and Guangzhou for which the overseas trade is prosperous. Marco Polo once described the prosperity for the capital of Yuan Dynasty: "The import of all the items is just like the ceaseless flow. Just one item of silk, the number of vehicles that enter the city each day can be calculated in thousands. Around the capital of this country, there are about two hundred cities with different distances from the capital. Each city has merchants who come here for the sales of commodity; this city is a city with the prosperity of business." (Charignon, 2004, p. 313) The governance of Yuan Dynasty became more and more stabilized by the day pass, with the social stability, the peaceful life of people, the prosperity of economy, the number of population naturally increases gradually, the demand of labor from the society was no longer in a harsh, therefore, the rulers expected to enhance the increase of population through the pattern of the levirate marriage.

\subsubsection{The Reason on the Cultural Level}

During the governing assistance of Yelv Chucai, he had been actively recovering the achievements in culture and education and advocated the implementation for the proposal of "ruling the country with Confucianism. Ogodei followed his beneficial suggestions for the application of officials from Han Chinese and selected a lot of scholars from Han Chinese to undertake key posts in the government to speed up the combination for the culture of the Mongolian and Han, improve the capability of governance and the level of Chinese localization for the aristocrats of Mongolians in Yuan Dynasty for which it enhanced the prosperity of economy in Yuan Dynasty.

Before and after the establishment of Yuan Dynasty, Kublai applied a group of famous Confucianists from the central plateaus such as Liu Bingzhong, Zhang Wenqian, Dou Mo, Hu Qijue, etc., to continuously influence the ruler of Yuan Dynasty with the traditional Confucianism ideology from the central plateau. Emperors of generations in Yuan Dynasty after Kublai received the culture and education of Han Dynasty since childhood for which not only they can actively absorb the intellectuals of Han Chinese into the ruling class, they can also consolidate their achievements for the Chinese localization available with the legal systems. Under the advocacy of the civil officials of Han Chinese for the abolishment, the government increased the limitations on the levirate marriage among Han Chinese starting from the period of Chengzong, many cases of which the one who succeed requests for the levirate marriage were all offered with support. During the governance of Renzong and Yingzong, the compilation of Tong Zhi Tiao Ge (通制条格) and The Collection of Laws of Yuan Dynasty (元典 章) was completed, the code of Yuan Dynasty took the process of a record for the trial of the case as the feature, 
of which many of the results for the trial were quoted with the precedents, the release of large number of laws for the prohibition of Han Chinese from the levirate marriage, the limitation of Mongolians and Se Mu people for the levirate marriage deprived the legal accordance for the levirate marriage among the Han Chinese and the south people, the situation for the levirate marriage among the Mongolians and Se Mu people became fewer and fewer. During the period of Wenzong, heroic women who observed mourning of their husbands who had passed away were awarded for multiple times for which the chastity of women was considered as an honor in the social morality. During the period of Huizong, the government further released the order of "prohibition for Semu People to accept his uncle's wife as his wife", the situation of which the nephew accepted his uncle's wife as his wife among the Semu people was eradicated. After the abolishment of Tai He Lv, the customs which had always been followed was prohibited since then. Not only did the emperors recommend but also maintain the morality of Confucianism, the Mongolian ministers who had been deeply immersed in the culture of Confucianism gradually became dubious for the reasonability for the levirate marriage. His chief investigator Wu Gu Sun Liang Zheng reported to the Emperor Yuan Shun: "Law and discipline rites are originated from the heaven for which it cannot be changed, the legislative officials held the opinion that the people may not be limited by this law and discipline rites, respective nations shall follow their own customs and that is fine. That is to say, Han Chinese and South people should follow the law and discipline rites, Mongolians and other minorities may not follow it. On the surface, it seems a respect for the law and discipline rites. Actually it is an act that damages the law and the discipline rite and an insult to the laws and discipline rites." (Song, 1999, p. 2865) This inscription stated the harm which may be generated by the levirate marriage from the angle of morality in the manners of Han Chinese for which it can be seen that the Confucianism culture had the dominant ruling position in the process of social operation after the late stage of Yuan Dynasty. The fixed pattern of thinking which is against the values of Chinese people for the grassland people had been broken.

After the inheritance, a development for more than a thousand years, the culture of Han has a deep historical value of accumulation and dissemination, in the meantime it also has a higher inclusiveness and assimilative capacity. The Mongolian ruler listed the south people as the lowest level of the society, and they expected to raise the culture of Mongolians during Yuan Dynasty to the top point in the system of social value through the high-pressure policy for the Han Chinese. However, if the Mongolians want to enslave the Han Chinese, they must learn and command the national culture that is higher than the culture of the Han Chinese. The extremely high penetration of culture from Han Chinese re-established the traditional morality system of Confucianism in the process of study and acceptance of the Mongolian rulers for the system of culture and value, the original customs and habits of the minorities and their fixed policies became a minute by the pass of which the levirate marriage is one of the policies.

\subsubsection{The Awakening of Female Consciousness}

The awakening of female consciousness is mainly reflected on the two aspects which are the autonomy of marriage for unmarried girls and the autonomy of marriage for married women, it is the correct cognition and evaluation of a female for their own value, it is also the doubt and overturn to the traditional cultures and customs. For women who have lost a husband, their female consciousness is reflected that not only can they choose for the reintegration with the one who agrees in opinion, they can also choose to observe the mourning for their husbands who have passed away to be faithful to her husband unto death. Under the condition of mutual willingness of both the one who succeeds and the succeeded, the levirate marriage is compliant to the expression of women's emotion. It may help them achieve the autonomy of marriage. However, under most of the situations, the levirate marriage violates the willingness of women for marriage, deprives the option of women for remarriage. It can be seen from the cases listed above, most of the Han women cannot completely accept the pattern for the levirate marriage, the conduct of succession were generally continued by the force of the husband's family for which the autonomy of women for marriage was seriously harmed. In the cases of Ding Dingnu, Niu Wang'er and Li E'er etc. at the beginning of Yuan Dynasty, all the succeeded ones were not willing to be succeeded. However, under the force of the authorities by the ruler, they had to follow the result of the judgment. In the cases of Zhang Baonu, Liu Guaiguai and A Duan at the middle and late stage of Yuan Dynasty, the succeeded successfully maintain their right for the option of marriage by the transformation of the ruler's attitude. The ancient people were ashamed of lawsuits, unless it is totally necessary, they would not file a lawsuit against their family on court. However, women in these cases dared to resist against the right of husbands, they evenly publicly resisted against the family of their husband for which it showed the great improvement of women in Yuan Dynasty for their autonomy as female compared those in the past dynasties.

Han women in Yuan Dynasty were not like women in other dynasties who were shackled by the chains of feudal ethics. The Mongolian women and women of other minorities enjoyed a high position in their family. In the 
process of combination for the cultures of multiple nations, the awareness of Han women for right will naturally be enhanced continuously. Many women who had lost their husbands dared to break the restrain of their family; they were fearless for the pressure from the policy for which they chose autonomously for the remarriage and object of remarriage. In Yuan Drama, there are many topics with the theme of the awakening of women's consciousness; it has also established many female images who dare to actively pursue for the happiness of marriage, such as Ye Qin'er in the Three Visits to the Peach Garden, Tan Ji'er in the Wang Jiang Ting etc. Although most of the articles are for the praise of unmarried girls, it reflects the attitude of Han scholars in Yuan Dynasty towards the social position of females from one side, it also reflects the tendency of people in Yuan Dynasty for the judgment on the value of marriage. Under the social environment of which the freedom for the marriage of females was greatly advertised and the female consciousness had been improved as a whole, the levirate marriage was resisted by women in the respective levels of the society due to its limit on the scope of selection for the object of remarriage for females and the suppression on the right of women or the autonomous selection of marriage for which its feasibility was gradually diminished.

\section{Conclusions}

Family is the basic element for the composition of the society, the policy for the marriage and family is the situation that reflects the overall appearance of the society to the most. The appearance and existence for the levirate marriage have the deep social and historical reasons which are closely related with the respective aspects such as economy, culture and politics. In the beginning when the Mongolian rulers entered and hosted the central plateaus, they tried to influence the Han Chinese with their social customs and habits to substitute the culture of Han Chinese. However, with the revitalization of economy in Yuan Dynasty and the tendency of stabilization for the society, in addition to the Chinese localization from the top to the lower level inside the system of the ruler, the traditional ideology of Confucianism was penetrated into all the aspects of social life again, not only did the Han women who were immersed by the culture of Confucianism objected the levirate marriage, even the Mongolian women who considered the levirate marriage as the traditional law and other minority women gradually objected being succeeded. The research on the conflict between the culture of law in Mongolia and the culture of law at the land of Han during Yuan Dynasty is helpful to clarify the important value In the back of the legal system for which it has an active theoretical significance.

\section{References}

Charignon, A. H. J. (2004). The Journey of Marco Polo. Beijing: Zhonghua Book Company.

Chen, G. H., Zhang, F., Liu, X., \& Dang, B. H. (2011). The Collections of Laws of Yuan Dynasty. Beijing: Zhonghua Book Company.

Fang, L. G. (2001). Correction and Annotation of Tong Zhi Tiao Ge. Beijing: Zhonghua Book Compny.

Liu, Y. S. (2019). A Study on Ögedei Qa'an's Levirate Marriage with Činggiz Khan's Other Wives: Focusing on Qürghïghuatanï Khatun. Ethno-national Studies, 1, 86-141.

Liu, Z. W. (2004). Liang Fangzhong Collections. Guangzhou: Sun Yat-Sen University Publishing Press.

Minochera, R., Dudac, P., \& Jaeggia, A. V. (2018). Explaining marriage patterns in a globally representative sample through socio-ecology and population history: A Bayesian phylogenetic analysis using a new supertree. Evolution and Human Behavior, $176-187$. https://doi.org/10.1016/j.evolhumbehav.2018.11.003

Moore, E. (2015). Forms of Femininity at the End of a Customary Marriage. Gender \& Society, 29, $817-840$. https://doi.org/10.1177/0891243215599646

Song, L. et al. (1999). The History of Yuan. Beijing: Zhonghua Book Company.

\section{Copyrights}

Copyright for this article is retained by the author(s), with first publication rights granted to the journal.

This is an open-access article distributed under the terms and conditions of the Creative Commons Attribution license (http://creativecommons.org/licenses/by/4.0/). 